\title{
Tantangan Konversi Bank Konvensional Menjadi Bank Syariah di Aceh Berdasarkan Qanun Lembaga Keuangan Syariah No 11 Tahun 2018
}

\author{
Rahmawati $^{1}$, Khairul Putriana ${ }^{2}$ \\ IAIN Lhokseumawe ${ }^{1}$, IAIN Lhokseumawe ${ }^{2}$ \\ rahmawati@iainlhokseumawe.ac.id¹, khairulputriana@gmail.com²
}

\begin{abstract}
The presence of the Islamic Financial Institution Qanun No 11 in 2018 is a special right for Aceh and has brought a breath of fresh air to the development of the Islamic banking industry in Aceh, a number of conventional banks in Aceh are required to convert to Islamic banks, The purpose of this study is to explain the procedure for accelerating the conversion of unconventional banks to Islamic banks in Aceh and to explain the challenges of banking institutions with the obligation to convert financial institutions in Aceh. The obligation to convert a conventional bank into a sharia bank is clearly as stipulated in article 6 points $e$ and $d$, although the process of converting a conventional bank to a sharia bank is not found directly in the qanun, but every bank that does the conversion must refer to BI regulations namely PBI No. 11 / 15 / PBI-2009, this is as explained in article 12 "before carrying out business activities, LKS must have a business license in accordance with the provisions of the legislation".
\end{abstract}

Keywords: Qanun, Islamic Bank, Conventional Bank

\begin{abstract}
Abstrak
Hadirnya Qanun Lembaga Keuangan Syariah No 11 tahun 2018 merupakan hak khusus bagi Aceh dan telah membawa angin segar bagi perkembangan industri perbankan syariah di Aceh, sejumlah bank konvensional di Aceh diwajibkan beralih ke Bank Syaria., Tujuan penelitian ini adalah untuk menjelaskan prosedur percepatan konversi bank inkonvensional menjadi bank syariah di Aceh dan menjelaskan tantangan lembaga perbankan dengan kewajiban mengkonversi lembaga keuangan di Aceh. Kewajiban untuk merubah bank konvensional menjadi bank syariah secara jelas diatur dalam pasal 6 huruf e dan d, walaupun proses konversi bank konvensional menjadi bank syariah tidak ditemukan langsung dalam qanun, tetapi setiap bank yang melakukan konversi. harus mengacu pada ketentuan BI yaitu PBI No. 11/15 / PBI-2009, hal ini sebagaimana dijelaskan dalam pasal 12 "sebelum melakukan kegiatan usaha, LKS harus memiliki izin usaha sesuai dengan ketentuan peraturan perundangundangan".
\end{abstract}

Kata kunci: Qanun, Bank Syariah, Bank Konvensional

\section{PENDAHULUAN}

Dalam perkonomian peran lembaga keuangan sebagai lembaga perantara ini sangat penting. Lembaga keuangan syariah di didirikan dengan tujuan mempromosikan dan mengembangkan penerapan prinsip 
prisnip islam, syariah dan tradisinya ke dalam transaksi transaksi keuangan dan perbankan serta bisnis yang terkait ${ }^{1}$.

Hadirnya qanun Lembaga Keuangan Syariah No 11 Tahun 2018 merupakan hak khusus bagi Aceh dan telah membawa angin segar bagi perkembangan industri perbankan syariah di Aceh, sejumlah bank konvensional yang berada di Aceh diwajibkan untuk melakukan konversi menjadi bank syariah, hal ini tentunya berdampak pula pada peningkatan perekonomian masyarakat Aceh.Qanun Lembaga Keuangan Syariah Merupakan wujud dan goverment driven Pemda Aceh dalam mengembangkan industri lembaga keuangan syariah lebih khusus perbankan syariah, Qanun ini telah diundang-undangkan secara sah pada tanggal 4 Januari 2019, dan dalam ketentuannya 3 tahun setelah qanun ini sah, seluruh lembaga keuangan di provinsi Aceh harus menerapkan prinsip syariah.

Mengingat Qanun ini berlaku sampai tahun 2021, bank besar dan bank menengah mulai mematangkan rencana ekspansi ke Provinsi Aceh. Upaya ini tidak terlepas dari diterapkannya penerapan Qanun Lembaga Keuangan Syariah (LKS) Aceh yang bakal diberlakukan paling lambat 2021. Perbankan konvensional yang sudah berada di Aceh saat ini juga sudah mulai mengkonversikan diri menjadi Bank Syariah.

Konversi bank umum konvensional menjadi bank umum syariah mempunyai syarat dan prosedur tersendiri karena memiliki perbedaan yang cukup mendasar, khususnya pada karekteristik antara perhitungan bunga dengan bagi hasil. Begitu pula mengenai akibat hukum yang timbul setelah bank umum konvensional dikonversi menjadi bank umum syariah tentu juga memiliki ciri khas tersendiri. Selain itu juga mengenai kedudukan kedua bank umum tadi dalam sistem perbankan di Indonesia serta mengenai kebijakan Bank Indonesia dalam mengembangkan kegiatan perbankan khususnya dalam kontribusinya terhadap proses konversi tersebut, karena saat ini konversi bank konvensional menjadi bank syariah dapat dijadikan sebuah sebuah alternatif pilihan bagi bank-bank yang ingin merubah kegiatan usahanya dari konvensional menjadi sistem operasional syariah.

Perbankan konvensional yang sebelumnya sudah mengganti dengan Bank Umum Syariah atau sudah memilik Unit Usaha Syariah harus menutup Cabang dan Unit konvensionalnya dan hanya membuka bank umum syariah saja. Saat ini semua perbankan konvensional sudah membenah diri untuk konversi menjadi Bank Syariah. Maka tujuan penelitian ini adalah mengetahui bagaimana prosedur konversi bank konvensional menjadi Bank Syariah berdasarkan Qanun LKS di Aceh. Selain itu juga apa tantangan lembaga perbankan dengan adanya 
Tantangan Konversi Bank Konvensional Menjadi Bank Syariah di Aceh Berdasarkan Qanun Lembaga Keuangan Syariah No 11 Tahun 2018

kewajiban konversi bank konvensional menjadi bank syariah berdasarkan Qanun LKS di Aceh.

\section{METODE PENELITIAN}

Penelitian ini merupakan penelitian kualitatif dan penelitian ini bersifat deskriptif, yaitu penulis mendeskripsikan tentang kewajiban konvrsi bank konvensional menjadi bank syariah, sehingga penulis mengetahui tentang prosedur atau SOP yang diterapkan pihak. Dan mengetahui pula tantangan yang dirasakan perbankan pada saat qanun LKS disahkan. Penelitian ini dilakukan pada perbankan di Lhokseumawe.

Dalam penelitian ini penulis menggunakan data primer dan data sekuder, karena perlu dipahami bahwa setiap penelitian selalu berkaitan dengan data, dan walaupun ada banyak macam klasifikasi data.

Data yang terkumpul dari hasil penelitian, maka akan dilakukan analisis data serta melakukan pengambilan kesimpulan dari data yang sudah terkumpul. Proses ini berlangksung selama pelaksanaan penelitian, yaitu pada awal penelitian sampai pada laporan penelitian. Reduksi data dimaksud untuk mempertegas, memperoendek, membuat fokus, dan membuat bagian yang tidak penting untuk mempermudah penarikan kesimpulan, dalam hal ini, reduksi data adalah langkah yang ditempun untuk menggolongkan dan membuat ringkasan singkat ke dalam urutan kajian yang berkaitan dengan konversi bank konvensional menjadi bank syariah.

\section{PEMBAHASAN}

Menurut POJK No 41 tahun 2019 konversi diartikan sebagai perbuatan hukum yang dilakukan oleh KCBLN untuk mengubah izin usaha KCBLN menjadi izin usaha Bank, dan selanjutnya dilakukan pencabutan izin usaha KCBLN.

Konversi bank konvensional menjadi bank syariah (Sutan Remi Sjahdeini, 2014). Sesuai dengan ketentuan pasal 5 Undang undang No 21 Tahun 2008 tentang perbankan syariah, menyangkut korversi bank konvensional menjadi bank syariah atau sebaliknya bank syariah menjadi bank konvensional, Indonesia mengambil sikap sebagai berikut:

1) Bank konvensional hanya dapat mengubah kegiatan usahanya berdasarkan prinsip syariah dengan izin bank indonesia

2) Bank Umum syariah tidak dapat dikonversi menjadi bank umum konvensional

3) Bank pembiayaan rakyat syariah tidak dapat dikonversi menjadi bank pengkreditan rakyat

Kewajiban konversi bank konvensional menjadi bank syariah terlihat jelas sebagaimana termaktub pada pasal 6 poin e dan $d$, meskipun proses 
konversi bank konvensional menjadi bank syariah tidak dijumpai secara langsung pada qanun tersebut, namun setiap perbankan yang melakukan konversi harus merujuk kepada peraturan BI yaitu PBI No 11/15/PBI2009, hal ini sebagaimana dijelaskan pada pasal 12 "sebelum menjalankan kegiatan usaha, LKS harus memiliki izin usaha sesuai dengan ketentuan peraturan perundang undangan".

Sistem perbankan nasional yang dianut di Indonesia adalah sistem perbankan ganda (dual banking system). Sistem ini menganut paham yang membolehkan bank untuk melakukan kegiatan usaha secara konvensional maupun berdasarkan prinsip syariah. Dual banking system mulai berlaku di Indonesia semenjak diamandemennya Undang-Undang No. 7 Tahun 1992 tentang Perbankan menjadi Undang-Undang No. 10 Tahun 1998. Salah satu isi dari amandemen undang-undang tersebut menyatakan secara tegas bank boleh beroperasi berdasarkan prinisp syariah. Undangundang perbankan juga mengizinkan bank konvensional beroperasi berdasa rkan prinsip syariah dengan membuka Islamic windows atau Unit Usaha Syria (UUS)2. Dalam hal ini, Indonesia mengikuti langkah Malaysia yang telah menerapkan terlebih dahulu konsep dual banking system semenjak tahun 1983 dengan diberlakukannya Akta Perbankan Islam (Islamic Banking Act).

Pasca amandemen undang-undang perbankan, pertumbuhan perbankan syariah di Indonesia meningkat dengan signifikan karena bank bisa membuka Unit Usaha Syariah. Di samping itu, untuk meningkatkan pertumbuhan perbankan syariah, bank konvensional juga dibolehkan menkonversi kegiatan usahanya berdasarkan prinsip syariah dengan syarat mendapatkan izin dari Otoritas Jasa Keuangan (OJK) (lihat Pasal 5, 6 \& 7 Undang-Undang No. 21 Tahun 2008 tentang Perbankan Syariah). Kegiatan konversi bank konvensional menjadi bank syariah mesti didukung namun dalam pelaksanaannya tetap harus memperhatikan asas perbankan yang sehat dan prinsip kehati-hatian sehingga dapat terciptanya kondisi perbankan syariah yang kuat dan konsisten dalam menerapkan prinsip syariah.

Mekansime pelaksanaan perubahan kegiatan usaha bank konvensional menjadi bank syariah selanjutnya diatur dalam Peraturan Otoritas Jasa Keuangan No. 64/POJK/03/2016 tentang Perubahan Kegiatan Usaha Bank Konvenional Menjadi Bank Syariah. Di atas telah dijelaskan bahwa perubahan kegiatan usaha bank konvensional menjadi bank syariah hanya dapat dilakukan dengan izin Otoritas Jasa Keuangan. Pemberian izin tersebut dilakukan dalam bentuk izin perubahan kegiatan usaha (Pasal 4 Peraturan OJk No. 64 Tahun 2016). (Amir Makmur Rukmana, 2010)Kemudian pada pasal 5 Peraturan OJK diatur ketentuan tentang kewajiban mencantumkan rencana konversi bank dalam rencana bisnisnya. Selanjutnya bank konvensional yang akan melakukan 
Tantangan Konversi Bank Konvensional Menjadi Bank Syariah di Aceh Berdasarkan Qanun Lembaga Keuangan Syariah No 11 Tahun 2018

perubahan kegiatan usaha menjadi bank syariah harus: menyesuaikan anggaran dasar, memenuhi persyaratan permodalan, menyesuaikan persyaratan Direksi dan Dewan Komisaris; membentuk Dewan Pengawas Syariah (DPS); dan menyajikan laporan keuangan awal sebagai sebuah bank syariah.

Melalui pemberlakuan qanun No 11 Tahun 2018, qanun tersebut memberikan kesempatan seluas-luasnya bagi pengusaha perbankan untuk membuka bank syariah baru melalui pembukaan bank baru. Dan untuk perbankan yang sedang menjalankan operasionalnya di aceh makan ini

Saatnya untuk melakukan konversi dari bank umum konvensional menjadi bank umum syariah. Konversi tersebut tentunya membawa dampak bagi hubungan kontraktual yang terjadi antara bank dengan pihak nasabah deposan. Konsekuensi yuridis konversi bank umum konvensional menjadi bank umum syariah adalah bank harus mencantumkan kata "syariah" setelah kata "bank", selanjutnya bank bersangkutan harus menyelesaikan hak dan kewajiban nasabah bank konvensional sebelumnya. Konversi juga membawa perubahan bagi hak dan kewajiban pihak bank dan nasabah deposan termasuk di antaranya pengakhiran dan perubahan hubungan kontraktual bank dan nasabah. Pengakhiran hubungan kontraktual terjadi jika nasabah memilih untuk tidak menjadi nasabah bank syariah hasil konversi maupun nasabah pada kantor cabang atau kantor cabang pembantu lain bank konvensional yang sama.

Jika nasabah memilih untuk tetap menjadi nasabah bank konvensional yang sama pada kantor cabang atau kantor cabang pembantu lain, maka hanya ada pemindahan hak dan kewajiban nasabah. Jika nasabah deposan memilih untuk menjadi nasabah bank syariah hasil konversi maka terjadi perubahan hubungan kontraktual yang meliputi jenis perjanjian, dasar hukum perjanjian, landasan filosofis, ruang lingkup atau substansi yang diatur, syarat sah perjanjian, subyek perjanjian dan jenis perjanjian. Konversi bank juga membawa perubahan pada produkproduk penghimpunan dana masyarakat seperti tabungan, deposito dan giro yang digunakan oleh nasabah deposan. Menyikapi fakta tersebut diatas, maka perlu kiranya penelitian ini dilakukan.

Adapun untuk menjadi bank syariah, bank konvensional memiliki prosedur ysitu Bank umum konvensional dapat mengubah kegiatan usahanya menjadi bank syariah dengan ijin Direksi Bank Indoneisa. Berdasarkan Pasal 16 ayat (2) UU No 10 Tahun 1988 tentang Perbankan. Menurut ketentuan Pasal 43 ayat ( 3) SK Direksi Bank Indonesia No. 32/34/ KEP/ DIR Tahun 1999 tentang Perubahan Kegiatan Usaha Bank Umum Konvensional menjadi Bank Umum Berdasarkan Prinsip Syariah dan Pembukaan Kantor Bank Berdasarkan Prinsip Syariah oleh Bank Konvensional dilakukan dengan dua tahap: 
1) Tahap persetujuan prinsip yaitu persetujuan untuk melakukan persiapan perubahan kegiatan usaha

2) Tahapan izin perubahan kegiatan usaha yaitu izin untuk melakukan kegiatan usaha Bank berdasarkan prinsip syariah setelah persiapan selesai dilakukan

Dalam melakukan konversi ada dua alternatif yang dapat ditempuh:

1) Mengeliminasi konsep bunga dari setiap bentuk pendapatan atas simpanan dan pinjaman dan hanya mengizinkan bank untuk mengenakan beban biaya pelayanan untuk menutup pengeluaran bank. Tetapi hal ini mengakibaikan bank menjadi tidak profitable dan akan dianggap sebagai lembaga pelayanan so sial yang dijalankan oleh pemerintah yang tidak bermanfaat karena tanpa hasil dan orang tidak akan menyimpan dananya di bank sehingga akan menurunkan sumber dana serta akan berakibat terhambatnya pertumbuhan ekonomi.

2) Perbankan syariah yang merupakan hasil konversi terutama produk yang dihasilkan harus segera dijalankan dengan prinsip bagi hasil dan berbagi resiko. Konversi dilakukan dengan melakukan Konversi Pasiva dan Konversi Aktiva.

Tantangan bank konvensional saat ini percepatan aspek legal, kemudian semua produk, aset dan bisnis yang ada di konvensional harus dialihkan ke Syariah dan lembaga keuangan itu meyakinkan nasabah bahwa mereka siap untuk mengalihkan ke Syariah baik itu dari nasabah tabungan maupun kredit. Adapun tantangan lainnya bagaiman memindahkan dana pihak ketiga dari dari bank konvensional ke bank syariah dimana dana di bank konvensional lebih besar daripada bank syariah.

\section{KESIMPULAN}

Hadirnya qanun Lembaga Keuangan Syariah No 11 Tahun 2018 merupakan hak khusus bagi Aceh dan telah membawa angin segar bagi perkembangan industri perbankan syariah di Aceh, sejumlah bank konvensional yang berada di Aceh diwajibkan untuk melakukan konversi menjadi bank syariahKewajiban konversi bank konvensional menjadi bank syariah terlihat jelas sebagaimana termaktub pada pasal 6 poin e dan $d$, meskipun proses konversi bank konvensional menjadi bank syariah tidak dijumpai secara langsung pada qanun tersebut, namun setiap perbankan yang melakukan konversi harus merujuk kepada peraturan BI yaitu PBI No 11/15/PBI-2009, hal ini sebagaimana dijelaskan pada pasal 12 "sebelum menjalankan kegiatan usaha, LKS harus memiliki izin usaha sesuai dengan ketentuan peraturan perundang undangan".

Adapun untuk menjadi bank syariah, bank konvensional memiliki prosedur ysitu Bank umum konvensional dapat mengubah kegiatan 
Tantangan Konversi Bank Konvensional Menjadi Bank Syariah di Aceh Berdasarkan Qanun Lembaga Keuangan Syariah No 11 Tahun 2018

usahanya menjadi bank syariah dengan ijin Direksi Bank Indoneisa. Tantangan bank konvensional saat ini percepatan aspek legal, kemudian semua produk, aset dan bisnis yang ada di konvensional harus dialihkan ke Syariah dan lembaga keuangan itu meyakinkan nasabah bahwa mereka siap untuk mengalihkan ke Syariah baik itu dari nasabah tabungan maupun kredit. Adapun tantangan lainnya bgaiman memindahkan dana pihak ketiga dari dari bank konvensional ke bank syariah dimana dana di bank konvensional lebih besar daripada bank syariah.

\section{DAFTAR PUSTAKA}

Andri Soemotro. (2009). Bank dan Lembaga Keuangan Syariah, Jakarta: Kencana.

Anwar Sanusi. (2013). Metodelogi Penelitian Bisnis, Jakarta: Salemba Empat.

Izza Hawari Husna, Efektifitas Konversi Bank Konvensional Menjadi Bank Syariah Pada Bank x. Skripsi mahasiswa universitas Sumatera Utara.

Sofyan, S. Harahap. (2009). Akuntansi Perbankan Syariah, Jakarta: LPEE Usakti.

Lusiana Indra. (2019). pengaruh konversi bank konvensional menjadi bank syariah terhadap resiko kebangkrutan studi kasus pada bank Aceh syariah, Jurnal Ekonomi dan Bisnis Universitas Udanaya, Vol 8 No 62019.

Mahmud Yunus. (1998). Kamus Arab-Indonesia, Jakata: PT Hidakarya Agung.

Muhammad Syafi'i Antonio. (2001) Bank Syariah dari Teori ke Praktik, Jakarta: Gema Insani.

Monzer Kahf. (2007). Islamic banks and economic development, kabir Hassan MervinLewis, (Eds) Hanbook Of Islamic Banking. UK : Edward Elgar Publisher.

Muhammad Umar Chapra. (2000). Sistem moneter Islam. Jakarta : Penerbit, Gema Insani.

Muhammad. (2008). Metodologi Penelitian Ekonomi Islam. Jakarta: Rajawaji Pers.

Pusat pembinaan dan pengembangan bahasa departemen pendidikan dan kebudayaan kamus besar bahasa indonesia, Jakarta: Balai Pustaka.

Rahmi Wati Ria (2004). konversi bank umum konvensional menjadi bank umum syariah berdasarkan UU No 10 Tahun 1998, jurnal Hukum dan Pembangunan Juli- Desember.

Rachmdi Usman. (2012) Aspek Hukum Perbankan Syari'ah di Indonesia, Jakarta : Sinar Gravika.

Sutan Remi Sjahdeni. (2014). Perbankan Syari'ah produk -produk dan Aspek Hukumnya, Jakarta: Kencana. 
Suharsimi Arikunto. (1998). Prosedur Penelitian suatu pendekatan Praktik Jakarta: PT Rineka cipta.

Sugiono. (2011). Metode Penelitian Kuantatif Kualitatif dan $R$ dan D. Alfa Beta: Bandung. 